\title{
Cross-border E-commerce Logistics Path Innovation Based on the Background of "Belt and Road"
}

\author{
Wenjing Qiu \\ School of Management Engineering, Zhengzhou University, No.100 Science Avenue, Zhengzhou, \\ China \\ 422061857@qq.com
}

Keywords: "Belt and Road”, Cross-border logistics, Innovation path.

\begin{abstract}
With the deepening of the "One Belt, One Road" strategy, the development of cross-border e-commerce with countries along the route has become an important strategy for China's foreign trade and economic cooperation. However, China's development along the "Belt and Road" countries in cross-border logistics is still lagging behind. This paper summarizes the existing logistics modes of cross-border e-commerce, and points out the existing problems of the existing logistics modes in the countries along the "Belt and Road", and proposes an innovative path for cross-border e-commerce logistics, which provides powerful cross-border e-commerce logistics, provide a strong support system for crossborder e-commerce logistics to create internationally competitive multinational ecommerce.
\end{abstract}

\section{Introduction}

The current development of cross-border e-commerce is an important new economic growth mode for China's foreign trade and economic cooperation. On August 31, 2018, the Standing Committee of the National People's Congress passed the "E-commerce Law", which is the first comprehensive regulation in the field of e-commerce in China. The introduction of the e-commerce law has also made relevant regulations on the development of cross-border e-commerce, which has made institutional development of cross-border e-commerce development, and encouraged SMEs to use cross-border e-commerce to go abroad. Trade between countries along the "Belt and Road" through cross-border e-commerce is an inevitable trend in the development of international trade today. There are many conveniences for developing cross-border e-commerce in countries along the "Belt and Road": on the one hand, to promote the development of cross-border e-commerce in countries along the "Belt and Road", a series of preferential policies have been introduced; on the other hand, The countries along the route have continuously improved the construction of railways, aviation, ports and pipeline infrastructure, and opened the freight trains to the countries along the route. The countries along the "Belt and Road" involve 65 countries and regions, and their total population accounts for $63 \%$ of the global population, total GDP accounts for about $29 \%$ of the world, and the development of cross-border e-commerce has huge consumption potential, demand and market.

However, there are still many problems in developing cross-border e-commerce with countries 
along the "Belt and Road", and logistics among countries along the route is the primary issue. Since the development of cross-border e-commerce across countries along the "Belt and Road"across Europe, Africa and Asia, there are high requirements for cross-border logistics. Therefore, the innovative logistics model for the countries along the "Belt and Road" is urgently needed for the development of cross-border e-commerce. The cross-border logistics models that countries along the "Belt and Road" countries rely on include high-speed rail logistics, international multimodal transport, and cross-border e-commerce logistics. At present, China and the countries along the "Belt and Road" have planned six high-speed railway lines such as Pan Asia, Central Asia and Europe and Asia. However, due to the high cost of high-speed railway logistics model and long construction period, the high-speed rail logistics model cannot be the main-stream model. The development of international multimodal transport along the "Belt and Road" countries requires the improvement of infrastructure communication and construction of sea, land and railway and the standardization of logistics model standards. However, the logistics development of the countries along the line is still in its infancy. Different logistics models and infrastructure construction in different countries still need to be combined. With the cooperation with countries along the "Belt and Road" in cross-border e-commerce, the cross-border logistics model has become more and more widely used in countries along the "Belt and Road" and has become a key development logistics model, but along the "Belt and Road" countries. The development of cross-border logistics is still at a low level of development. For example, there are long-term cross-border logistics transportation in the countries along the Belt and Road. It takes a long time, high cost, difficult return, incomplete after-sales service, and backward construction of logistics infrastructure. Need to innovate cross-border e-commerce logistics model (Wenlin Chen, 2016). At present, the countries along the "Belt and Road" have developed rapidly in cross-border e-commerce in Russia, Southeast Asia and West Asia. The market potential is large. The cross-border e-commerce logistics model relies on international express delivery, overseas warehousing and international logistics. However, these cross-border logistics models cannot be coordinated in terms of low cost and short time. Therefore, it is necessary to innovate the cross-border e-commerce logistics model of countries along the "Belt and Road".

Based on the specific conditions of the countries along the "Belt and Road", this paper analyzes the problems existing in the cross-border logistics network, infrastructure, comprehensive services, cross-border logistics enterprises and logistics modes along the countries, and proposes an innovative cross-border logistics model path. Further promote the development of cross-border ecommerce in countries along the "Belt and Road".

\section{Literature review}

Domestic and foreign scholars' research on the "Belt and Road" focuses on development status, problem disputes, investment differences and infrastructure construction. Xianjie Shen believes that through the implementation of the "One Belt, One Road" strategy, China and Europe, Asia and Africa can achieve economic complementarity, industrial upgrading, resource sharing, enhance the economic development of China and neighboring countries, and open a new situation of international regional economic cooperation (Xianjie Shen, 2014) . Jialing Zou and others found that China's trade links with countries along the Belt and Road Initiative are getting closer and closer, and each other's trade export dependence is deepened. However, the amount of GDP contributed by countries in China's different provinces to the "Belt and Road" is different. It is determined by geographical location (Jialing Zou, 2015). Wuqi Zhou believed that due to geographical constraints and traffic restrictions, China's direct investment in countries along the "Belt and Road"is mainly concentrated in Southeast Asia, Central Asia and other countries. There is 
a problem of excessive direct investment, so it is necessary to avoid pile-up investment. Promote sustainable development with countries along the Belt and Road Initiative (Wuqi Zhou, 2015).

At present, the economic growth mode of traditional trade is developing at a slow pace. Ecommerce is developing rapidly in China. In order to better promote trade and economic exchanges with countries along the Belt and Road, it is necessary to combine the"Belt and Road"with the development of e-commerce. More and more scholars recognize the importance of "One Belt, One Road"and cross-border e-commerce development, but there are not many related studies. Jingfei Jiang pointed out that the development of cross-border e-commerce in countries along the "Belt and Road"has the characteristics of wide coverage, large market potential, rich historical and cultural heritage, and rapid development (Jingfei Jiang, 2018). Nina Zhu pointed out that cross-border ecommerce trade with the "Belt and Road" countries can reduce intermediate links, promote the development of SMEs, establish Chinese brands, and expand the transaction volume with neighboring countries(Nina Zhu, 2015).FeiqiongWei pointed out that the“One Belt, One Road”strategy has provided many conveniences for bilateral countries' trade exchanges, such as the establishment of the Asian Infrastructure Investment Bank, the Silk Road Fund, the China-Pakistan Economic Corridor, and the China-European class. Therefore, it is necessary to make good use of the "One Belt, One Road" strategy (Feiqiong Wei, 2017). Xueli Yan pointed out that more and more small and medium-sized enterprises are developing foreign trade through cross-border ecommerce, and the government has also introduced several policies to support the development of cross-border e-commerce (Xueli Chu, 2016).Hyuksoo Cho et al pointed out that the cross-border ecommerce B2C model is no longer limited to the domestic market, and consumers are increasingly buying products through major online shopping sites such as Amazon and eBay. Researchers conduct empirical tests on panel data for each country through logistics and regulation to study the various determinants that influence overseas direct purchases (Hyuksoo Cho, 2017).Do not add any text to the headers (do not set running heads) and footers, not even page numbers, because text will be added electronically.

China's development along the "Belt and Road" countries in cross-border e-commerce is still at a low level, mainly because cross-border logistics has constrained its development. Dongfang Wang pointed out that the development level of logistics plays an important role in the development of national trade. However, according to the logistics performance related to the countries along the "Belt and Road", the logistics development level of the countries along the "Belt and Road" is still relatively backward(Dongfang Wang, 2018).Xia-heng Zhang pointed out that cross-border logistics in China currently has long-term cross-border logistics and transportation, high transportation costs, high rate of adjustment, difficult return and exchange, and risks in different countries such as politics, economy, culture, customs, and exchange rate changes. Trade protection policies are more restrictive (Xiaheng Zhang, 2016). Shouxue Wu pointed out that cross-border logistics has a complete logistics and service system in the domestic logistics and logistics in the destination country, but there is a lack of synergy between domestic logistics, cross-border transportation, and destination country logistics and distribution (Shouxue $\mathrm{Wu}, 2018$ ). Hongwei Li pointed out that the current development of cross-border logistics is closely integrated with big data and Internet of Things, but countries along the "Belt and Road" are still relatively backward in cross-border logistics technology, lacking high-end cross-border logistics technology to support (Hongwei Li, 2018). Peiju Wu believes that there are few studies on the analysis of e-commerce logistics business model through big data. The author proposes a mixed content analysis framework to explore the e-commerce logistics management by exploring the e-commerce logistics business model of unstructured big data (Peiju Wu, 2018). Stephen $\mathrm{CH}$ Leung introduced the problem of cross-border logistics through fleet management, and proposed a preemptive goal planning model for multi-objective cross-border logistics problems, which can be found by adjusting the target 
priority according to the importance of each target. The flexibility and robustness of the proposed model (Stephen C.H. Leung, 2006).

At present, most scholars' research on cross-border logistics mode is to find out the countermeasures for cross-border logistics from the problems existing in the cross-border logistics model. The cross-border logistics solutions are too general and single, and no practical solutions are proposed. The solution to the problem. Based on the "One Belt, One Road" background, this paper proposes an innovative path for cross-border logistics mode based on the existing problems of cross-border logistics models along the "Belt and Road".

\section{Problems with cross-border logistics models}

\subsection{Cross-border logistics network system imperfect}

With the popularization of related technologies such as big data and Internet of Things, crossborder e-commerce has been closely connected with the Internet, and it is an inevitable trend to improve the cross-border logistics network system with countries along the "Belt and Road". However, there are still many difficulties and obstacles in establishing a cross-border logistics network system with countries along the "Belt and Road". On the one hand, the "Belt and Road" involves different countries, and there are differences in the relevant e-commerce export policy regulations, and some countries along the line have barriers to the construction of cross-border logistics networks. The technical level of logistics networks along the country varies greatly, including West Asia and South Asia. The e-commerce network logistics technology is lagging behind, which makes the construction of cross-border logistics network quite complicated. In the cross-border logistics, there is no supporting cross-border logistics network system from the outbound, distribution, and storage of goods; on the other hand, along the "Belt and Road" The country involves many small languages, and the countries along the "Belt and Road" are mostly developing countries, which make cross-border logistics information mismatched. There are still cross-border logistics network resources in the countries along the "Belt and Road" cost, crossborder logistics network Uneven resources are distributed, lack of high-end logistics network technical support, and weak ability to connect with global cross-border logistics network resources.

\subsection{Incomplete construction of cross-border logistics infrastructure}

Although the "Belt and Road"strategy has promoted the development of cross-border ecommerce in countries along the route, the overall development level of cross-border e-commerce in countries along the "Belt and Road" is still in the primary development stage, and the countries along the route lack cross-border e-commerce that dominates the industry. The main reason for the development model is that cross-border logistics is the biggest obstacle to the development of crossborder e-commerce in countries along the route. Cross-border logistics is divided into three parts: domestic logistics, international logistics, and destination country logistics. At present, China's domestic logistics transportation channels are basically complete and perfect, but in the international logistics and destination country logistics, due to the "One Belt and One Road", many countries along the line, domestic The external logistics environment is different. There is a lack of overall operation and coordination in the construction of cross-border logistics infrastructure. It is poor in terms of convergence and transparency of information (Fang Ji, 2015), and the logistics infrastructure of countries along the "Belt and Road" The planning has different requirements, standards and programs, and also involves a variety of modes of transportation. Different modes of transportation have different requirements on the shape and weight of the products, which makes the logistics of the countries along the "Belt and Road" not smooth. Therefore, it is difficult to 
coordinate different logistics infrastructures in countries along the route.

\subsection{Cross-border logistics comprehensive service system is not perfect}

The development of cross-border e-commerce in China is mainly dominated by manufacturing industries such as food and electronic products. Therefore, most cross-border logistics services are only excellent in certain areas, but China and cross-border electronics are developing along the "Belt and Road" countries. It involves multiple fields and multiple products, and different crossborder e-commerce customers have different requirements for cross-border logistics services. Therefore, cross-border e-commerce with countries along the "Belt and Road" should provide multi-level and multi-demand cross- Logistics services (Xudong Li, 2015). At present, countries along the "Belt and Road" have problems of low efficiency, high cost, single function and scattered resources in cross-border e-commerce logistics services. The procedures in customs clearance, commodity inspection, foreign exchange settlement and tax refund are cumbersome, and the time is too long. The comprehensive logistics services are still in the extensive stage.

\subsection{Cross-border logistics enterprises do not cooperate}

According to the logistics performance index and its sub-indices in 51 countries and regions along the "Belt and Road", the performance level of logistics in countries and regions along the "Belt and Road" is not high and the gap between different countries is significant (Dongfang Wang, 2018), which is related to "The development of cross-border e-commerce resources in the countries along the Belt and Road is still relatively fragmented. No logistics company has an important position. The current cross-border logistics is mainly monopolized by the four international logistics companies FedEx, UPS, DHL and TNT. Therefore, to promote the development of cross-border logistics in countries along the "Belt and Road", it is necessary to coordinate different cross-border logistics enterprises and share logistics resources. However, due to the current "Belt and Road" involving multiple countries, Central Asia and West Asia are affected by the turmoil in Syria and Iraq, and there are many restrictions on trade protection policies along the route. Different countries are dealing with cross-border logistics networks in relevant laws and regulations. There are different requirements in terms of management policies, and there are many restrictions on trade protection policies. Domestic logistics information and overseas logistics information are not well connected and resources are scattered, which makes the development of cross-border logistics enterprises related to the "Belt and Road" countries uncoordinated. Cross-border logistics companies have also failed to develop synergistically.

\subsection{Cross-border logistics model is not flexible}

In recent years, the rapid development of cross-border e-commerce has become a new economic growth point for China's foreign trade. The implementation of the "One Belt, One Road" strategy has further promoted the development of cross-border e-commerce in China, but with cross-border e-commerce in countries along the "Belt and Road" Development is still at a low level, mainly because cross-border logistics has constrained its development. Most of the countries along the "Belt and Road"are developing countries. Therefore, the choice of cross-border logistics mode is still relatively simple, which reduces the efficiency of cross-border logistics to a certain extent. At present, the cross-border e-commerce logistics business along the "Belt and Road" countries is mainly undertaken by postal logistics, and postal logistics is still the main cross-border logistics service enterprise in China. However, because cross-border logistics involves economic, political, cultural, customs, commodity inspection, and institutional factors in different countries, there are 
cross-border logistics trade barriers, and countries along the route have different requirements in international transportation, and a single cross-border logistics model. It restricts the customer experience of cross-border e-commerce and requires a flexible cross-border logistics model. Only the modern logistics model of informatization, specialization and intensification can better support the development of cross-border e-commerce.

\section{Cross-border e-commerce logistics model path innovation}

The cross-border e-commerce logistics innovation path along the "Belt and Road" countries is aimed at "One Belt, One Road cross-border logistics. The specific path proposed by the problem appears, the specific path is shown in the figure below:

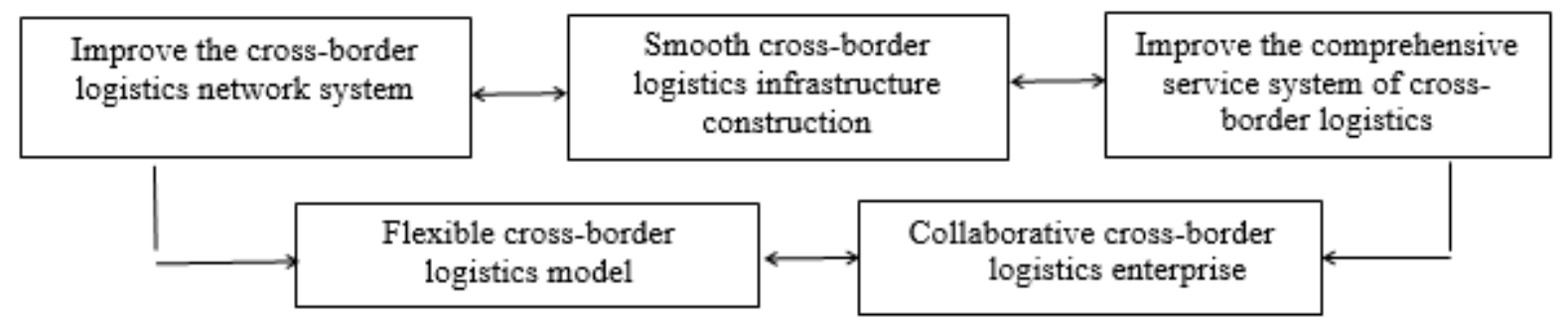

Fig.1 the specific path

\subsection{Improve the cross-border logistics network system}

Compared with the domestic e-commerce operation process, the cross-border e-commerce operation process is more complicated, including domestic goods collection and logistics, customs clearance of export goods, international logistics, customs clearance of imported goods, overseas logistics and distribution, and complex cross- The logistics operation process makes the construction of the cross-border logistics network system more complicated and difficult. The construction of the cross-border logistics network system needs to take the countries along the "Belt and Road" as a whole, and combine the domestic logistics and overseas logistics of the countries along the line with the Internet of Things, cloud computing, big data and block chain, and crossborder logistics network.

The system is connected, the international logistics network coordination system based on the value chain theory is constructed, the cross-border information system network, the logistics transportation network, and the three-in-one cross-border logistics network system of the operation network are well established(Yan Pang, 2015), realizing the integration of cross-border logistics distribution. Service (Qianli Dong, 2015). China and Russia, Southeast Asia and other countries have developed rapidly in cross-border e-commerce, so they have higher requirements for crossborder logistics. Therefore, it is extremely urgent for the country with rapid development of crossborder e-commerce to strengthen the cross-border logistics network system. China has cooperated with relevant government departments along the "Belt and Road" countries and regions to continuously expand the coverage of logistics, so that cross-border internal and external ecommerce enterprises, logistics enterprises, customs and other parties can coordinate with each other(Xiaojun Liu, 2016), improve cross-border logistics. Network system, real-time monitoring of goods destination, improve the level of cross-border logistics information, and build a cross-border logistics network system that ensures traceability throughout the entire process, so that the logistics delivery process is transparent and controllable, ensuring traceability and high timeliness of modern logistics. At present, China has signed cooperation agreements with Southeast Asian countries such as Thailand and Singapore to further implement the cross-border logistics network system. 


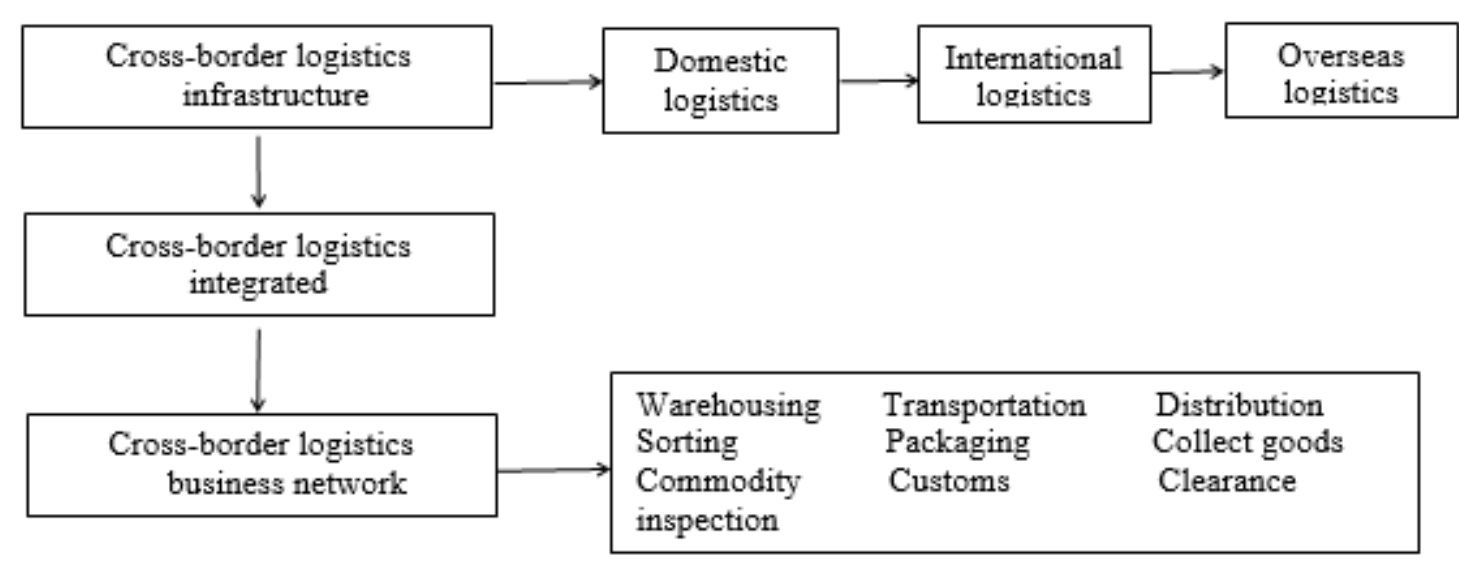

Fig. 2 the cross-border logistics network system

\subsection{Smooth cross-border logistics infra-structure construction}

The development of cross-border e-commerce between China and the countries along the "Belt and Road" will inevitably have higher requirements for the construction of cross-border logistics infrastructure along the "Belt and Road" countries. It should have a sound and efficient infrastructure construction to achieve cross-border transportation. Efficient, convenient and lowcost in the process. However, China and the countries along the "Belt and Road" have increased their cross-border e-commerce logistics distribution, but the time has been extended to countries along the "Belt and Road" countries such as South Asia and Central and Eastern Europe. Mainly because the countries along the "Belt and Road" are still at a relatively backward level in the construction of cross-border logistics infrastructure. The high-end cross-border e-commerce logistics technology is still not perfect, and the requirements of logistics in different countries are different. The development level of logistics in different countries Different, the level of crossborder logistics infrastructure construction along the "Belt and Road" countries is also relatively large, and the connection with Construction is not easy to obtain quickly. For the Construction of cross-border logistics infrastructure in the countries along the "Belt and Road", it is necessary to connect domestic logistics with international logistics. Starting from the overall planning, the countries along the "Belt and Road" should cooperate with each other along the line. The construction of logistics infrastructure in Southeast Asia, South Asia, Central Asia, West Asia, North Africa and other countries should be based on their own geographical characteristics, scientific planning for the implementation of railway hubs, airports and ports, in important cities along the "Belt and Road", Ports and border ports are well connected with the six major logistics channels, such as the Eurasian Continental Bridge, China, Mongolia and Russia, and guide crossborder e-commerce enterprises to rationalize the infrastructure such as distribution centers and communication networks, along with the "Belt and Road" The state establishes efficient, low-cost and convenient cross-border logistics channels, strengthens port infrastructure construction, and improves the level of port customs clearance, so that the cross-border logistics infrastructure construction along the "Belt and Road" countries can be interconnected. The construction of crossborder logistics infrastructure along the "Belt and Road" countries can start from the following three aspects, as shown in the following figure: 


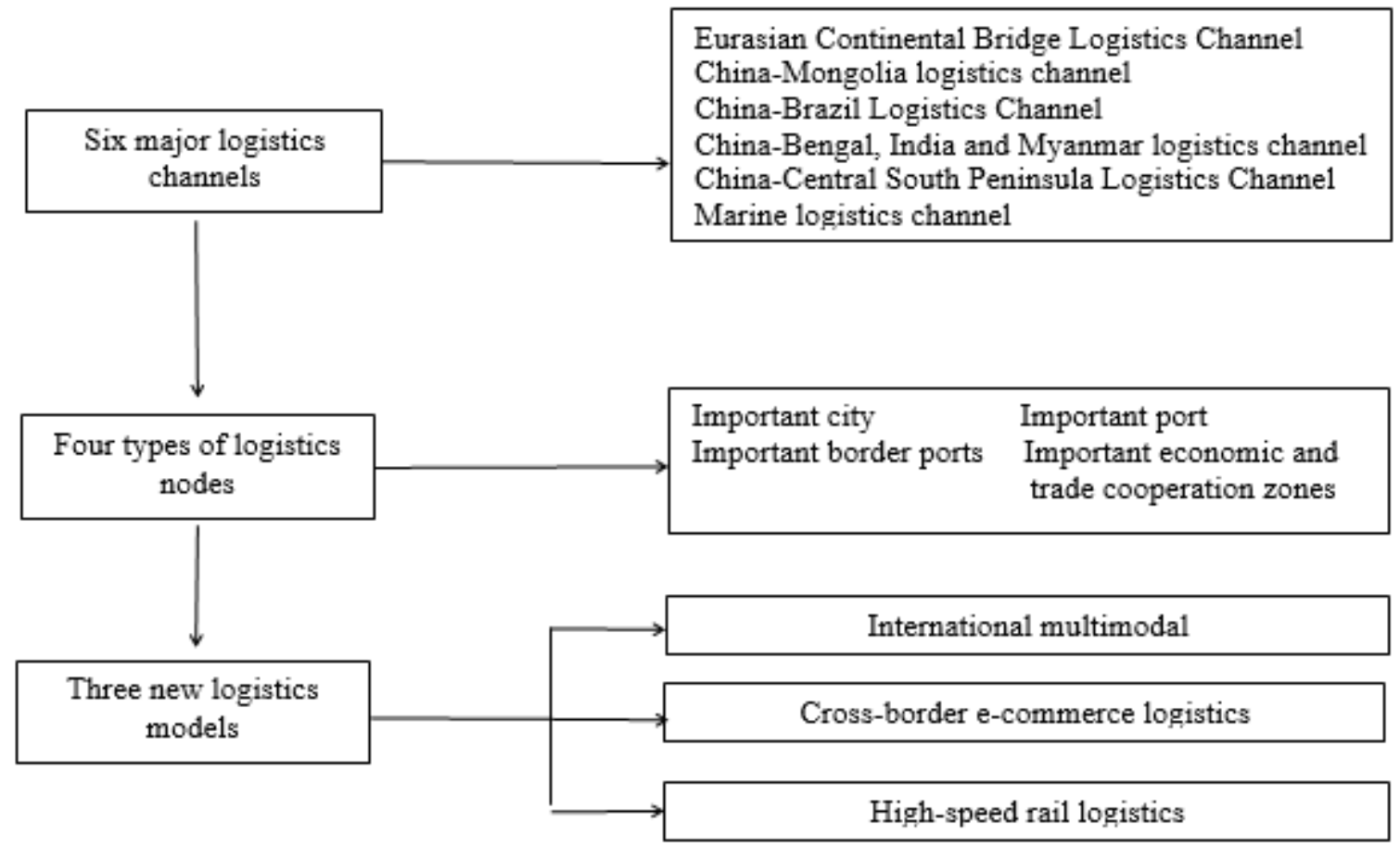

Fig.3 the construction of cross-border logistics infrastructure

\subsection{Improve the comprehensive service system of cross-border logistics}

With the further development of cross-border e-commerce in countries along the "Belt and Road", the requirements for improving the comprehensive service system for cross-border ecommerce logistics are more intense. Currently, the countries along the "Belt and Road" have the greatest development potential in Southeast Asia, and are expected to reach 2025. The amount of transactions through the Internet will reach 200 billion US dollars, which has diverse needs for time and cost of cross-border logistics. Therefore, it is urgent to improve the comprehensive cross-border logistics service system of the countries along the"Belt and Road".For the cross-border logistics comprehensive service system, we can adopt the supply chain management method to improve the comprehensive service system of cross-border logistics from the four dimensions of logistics, business flow, capital flow and information flow, providing warehousing management, cross-border logistics and order delivery. The orientation of cross-border logistics services, the establishment of an evaluation index system for international logistics service capabilities, to meet the comprehensive needs of cross-border logistics functions, logistics efficiency, logistics costs in countries along the "Belt and Road". Providing more favorable logistics service guarantees for countries along the "Belt and Road", reducing cross-border logistics costs, continuously improving international logistics control and control capabilities, intelligent moni-toring and coordination capabilities, international supply chain responsiveness and differentiated logistics service capabilities (Tao Tao, 2015).

\subsection{Collaborative cross-border logistics enterprises}

At present, cross-border logistics enterprises in China are severely divided. Cross-border logistics enterprises with single services are unable to meet the development of cross-border ecommerce. The whole process of cross-border logistics and its operations involve multiple countries and regions, and many international logistics. Enterprise. Cross-border logistics companies can 
adopt diversified cross-border e-commerce logistics cooperation methods such as investment, agreement cooperation, acquisition and mergers and acquisitions along the "Belt and Road" countries to strengthen logistics nodes in different countries and regions in the cross-border ecommerce international supply chain. Collaboration among enterprises to strengthen synergy. In the cooperation with cross-border logistics enterprises along the "Belt and Road", China and Mongolia, Russia's cross-border logistics companies can develop synergistically, China's demand for minerals and energy resources in Mongolia and Russia, and Mongolia, Russia to China's manufacturing industry. The demand for products enables different cross-border logistics enterprises to cooperate with each other through the Sino-Mongolian logistics channel to promote the efficiency of crossborder logistics enterprises; China currently has strong economic complementarity with the ASEAN region and the development of cross-border electronics in the ASEAN region. Business has huge market potential and provides many conveniences for the coordinated development of cross-border logistics enterprises in the ASEAN region(Yuna Di, 2018). On the other hand, China and Southeast Asia are friendly neighbors, and there is no major consumer demand and culture. The difference can be further coordinated with relevant logistics companies in Southeast Asia.

\subsection{Flexible cross-border logistics model}

The "Belt and Road" involves different countries and has different politics, cultures and customs. Therefore, the choice of cross-border logistics mode should be based on the specific conditions of the countries along the "Belt and Road". The choice of logistics mode is no longer limited to a single country. Cross-border e-commerce transactions have broken through the boundaries of the country and involve trading entities in different countries, so the transaction model of cross-border logistics has become more complicated (Xiaheng Zhang, 2016). The same cross-border logistics model cannot be applied to all countries along the "Belt and Road". Different cross-border logistics models have different advantages and disadvantages. To achieve the complementary advantages of different cross-border logistics models, international postal parcels are cheap but consume Duration, the construction of logistics infrastructure in some countries along the "Belt and Road" lags behind, making the coverage of postal parcels incomplete; the international express delivery service is good, it takes a short time, but the cost is high, and the "Belt and Road" is mostly a developing country. If the logistics cost is too high, it will be unable to pay; overseas warehouses, border warehouses and international logistics lines have geographical restrictions. At present, the overseas warehouse model is used more in cross-border logistics, but the overseas warehouse is more suitable for goods that are expensive, bulky, fragile, and cannot go through traditional logistics channels. Overseas warehouses should also consider the financial strength and risk resistance of the merchants themselves. With the continuous advancement of the "One Belt, One Road" strategy, for the selection of cross-border logistics models, cross-border e-commerce cooperation should be carried out according to the economic characteristics and different needs of the countries along the "Belt and Road", such as China's countries along the "Belt and Road". The investment in Russia and the ASEAN region is mostly concentrated in agriculture. The small-scale model in cross-border logistics is not suitable for the ASEAN region, and can be quantitatively transported through the cross-border logistics line (Xiaoyan Zhang, 2017). Therefore, the choice of cross-border logistics mode can not copy the traditional cross-border logistics model, which should be standardized, intelligent and customized. Countries along the "Belt and Road" in China should present a diversified cross-border e-commerce logistics cooperation model. The establishment of the crossborder logistics model innovation system lies in the choice of cross-border logistics mode, which is a hybrid cross-border logistics model. According to the actual needs of the cross-border ecommerce market along the "Belt and Road" countries, the advantages of various logistics modes 
are effectively utilized. Reduce cross-border logistics costs, shorten cross-border logistics cycles, and meet the needs of different consumers or commodities for logistics.

\section{References}

[1] Wenling Chen, Guanqun Mei. The overall structure and construction plan of the "One Belt, One Road" logistics system [J]. Economic Aspect, 2016(10): 19-26.

[2] Xianjie Shen, Jincheng Xiao. The New Situation of International Regional Economic Cooperation and China's "One Belt, One Road" Cooperation Strategy [J]. Macroeconomic Research, 2014(11): 30-38.

[3] Jialing Zou, Chunla Liu, Guoqing Yin, Zhipeng Tang. The Trade Pattern and Economic Contribution of China along the Belt and Road Initiative [J]. Progress in Geography, 2015, 34(05): 598-605.

[4] Wuqi Zou. Direct Investment Distribution and Challenges along the Belt and Road Initiative [J]. Reform, 2015(08): 39-47.

[5] Jingfei Jiang. Reflections on the development of cross-border e-commerce in China and the "Belt and Road" countries [J]. International Trade, 2018(06): 56-60.

[6] Nina Zhu, Li Wu. Analysis of the Potential and Trend of Cross-border E-Commerce Development in China under the "One Belt, One Road" Strategy [J]. Reform and Strategy, 2015, 31(12): 134-137.

[7] Feiqiong Wei. Countermeasures for Cross-border E-commerce Development under the "One Belt, One Road" Strategy Dividend [J]. China Circulation Economy, 2017, 31(03): 62-70.

[8] Xueli Chu. Financial interconnection and intercommunication support the development of cross-border ecommerce for small and medium-sized enterprises-based on the economic development of China and the countries along the Belt and Road, China and region [J]. China Circulation Economy, 2016, 30(11): 66-74.

[9] Hyuksoo Cho, Jungsun Lee: Searching for Logistics and Regulatory Determinants Affecting Overseas Direct Purchase:An Empirical Cross-National Study: The Asian Journal of Shipping and Logistics, Volume 33, Issue 1, Pages 11-18, March 2017.

[10] Dongfang Wang, Qianli Dong, Lixin Yu. Logistics Perfor-mance of China and Foreign Countries along the Belt and Road Initiative and China's Foreign Trade Potential [J]. China's Circulation Economy, 2018, 32 (02): 17-27.

[11] Xiaheng Zhang, Hailing Guo. Coordination of Cross-border E-commerce and Cross-border Logistics: Mechanism and path[J]. China Circulation Economy, 2016, 30(11): 83-92.

[12] Shouxue Wu. Collaborative Deficiency and Reaogistics [J]. Commercial Economic Research, 2018(09): 101-103.

[13] Hongwei Li. Difficulties and solutions for cross-border e-commerce logistics cooperation between China and the countries along the Belt and Road Initiative [J]. Foreign Economics and Trade Practice, 2018(04): 88-91.

[14] Peiju Wu, Kunchen Lin: Unstructured big data analytics for retrieving e-commerce logistics knowledge: Telematics and Informatics, Volume 35, Issue 1, 2018, Pages 237-244.

[15] Fang Ji, Xiaheng Zhang. Innovation and Development Trend of Cross-border E-commerce Logistics Mode[J]. China Circulation Economy, 2015, 29(06): 14-20.

[16] Xudong Li, Liren An. A Comprehensive Service System for Cross-border E-commerce Logistics Enterprises and Its Empirical Study[J]. China Circulation Economy, 2015, 29(11): 49-57.

[17] Dongfang Wang, Qianli Dong, Lixin Yu. Logistics Performance of China and Foreign Countries along the Belt and Road Initiative and China's Foreign Trade Potential [J]. China's Circulation Economy, 2018, 32 (02): 17-27.

[18] Yan Pang. Research on International Logistics Mode in Cross-border E-commerce Environment [J]. China Circulation Economy, 2015, 29(10): 15-20.

[19] Qianli Dong. The Industrial Linkage Development Based on the "One Belt, One Road" Cross-border Logistics Network_—The Top-Level Design Idea of Integrated Field Theory [J]. China Circulation Economy, 2015, 29(10): 3441.

[20] Xiaojun Liu, Bin Zhang. Cooperative Development of Cross-border E-commerce Logistics in China and the Countries along the Belt and Road Initiative [J]. China Circulation Economy, 2016, 30(05): 115-120.

[21] Tao Tao, Guangqian Li. Platform Evolution, Model Screening and Cross-border E-commerce Develop-ment Orientation [J]. Reform, 2015(09): 63-73.

[22] Yuna Di, Qing Lin. China's Investment Motivation, Distance Factors and Location Selection of the Belt and Road Countries [J]. China Soft Science, 2018(02): 168-176.

[23] Xiaheng Zhang, Hailing Guo. Coordination of Cross-border E-commerce and Cross-border Logistics: Mechanism and Path [J]. China Circulation Economy, 2016, 30(11): 83-92.

[24] Xiaoyan Zhang, Qiankun Sun. Trade Relations between China and the ASEAN Region in the Background of the "Belt and Road"[J]. Reform, 2017(09): 57-65. 